\title{
The need for multidisciplinary conservation: a case study of Ceratozamia (Zamiaceae, Cycadales) in eastern Mexico
}

\author{
Lilí Martínez-Domínguez, Fernando Nicolalde-Morejón \\ Dennis Wh. Stevenson, Quiyari J. Santiago-Jiménez \\ Octavio Rojas-Soto and Francisco Vergara-Silva
}

\begin{abstract}
As an evolutionary lineage cycads are rare, and the extinction risk is high for many species. The genus Ceratozamia, one of the most diverse in Mexico, is experiencing drastic reductions of its habitat. Ceratozamia is widely distributed along the Sierra Madre Oriental, a complex mountain range, in a region characterized by high ecological and cultural diversity. Since 1990, various conservation and management strategies have been applied to this taxon in Mexico but evidence for the effectiveness of these measures is lacking. Ceratozamia in the Mexican Sierra Madre Oriental is highly diverse and endemic, offering a model for analysing geographical distribution patterns with ecological niche modelling. It also presents an opportunity for assessing the success of conservation and management strategies that have been implemented in this area. Here, we examined three aspects that are considered fundamental for the development and evaluation of conservation strategies: (1) taxonomy, (2) ecology and (3) sociocultural anthropology. Our findings suggest a pessimistic outlook for the long-term survival of Ceratozamia species in their natural environment, indicating the need to review the current IUCN Cycad Action Plan for the genus. To improve the protection of Ceratozamia and other taxonomic and/or ecological assemblages, we encourage a multidisciplinary approach, with increased collaboration between natural and social scientists.
\end{abstract}

Lilí Martínez-Domínguez ${ }^{*}$ and Fernando Nicolalde-Morejón (Corresponding author, (D) orcid.org/0000-0003-1423-7474) Laboratorio de Taxonomía Integrativa, Instituto de Investigaciones Biológicas, Universidad Veracruzana, Xalapa, 91190, Veracruz, Mexico. E-mail enicolalde@uv.mx

Dennis WM. Stevenson The New York Botanical Garden, New York, USA

QuiYari J. SANTiago-Jiménez Facultad de Biología, Universidad Veracruzana, Xalapa, Veracruz, Mexico

Octavio Rojas-Soto Laboratorio de Bioclimatología, Red de Biología Evolutiva Instituto de Ecología, Xalapa, Veracruz, Mexico

Francisco Vergara-Silva Laboratorio de Sistemática Molecular, Jardín Botánico, Instituto de Biología, Universidad Nacional Autónoma de México, Coyoacán, Mexico

${ }^{*}$ Also at: Centro de Investigaciones Tropicales, Universidad Veracruzana, Xalapa, Veracruz, Mexico

Received 3 July 2019. Revision requested 12 September 2019.

Accepted 25 March 2020. First published online 24 March 2021.
Keywords Ceratozamia, cycads, ecological niche modelling, Mexico, multidisciplinary approach, protected areas, socio-cultural perceptions

Supplementary material for this article is available at doi.org/10.1017/So030605320000204

\section{Introduction}

The genus Ceratozamia (Zamiaceae: Cycadales) is wide1 ly distributed and highly diverse in Mexico, with 30 species occurring in the country (Calonje et al., 2019). Nearly $40 \%$ of Ceratozamia species are endemic to the Sierra Madre Oriental, a complex mountain range that harbours the greatest diversity of species belonging to this genus. Given the threatened status of Ceratozamia (the genus is listed on CITES Appendix I, and several species are categorized as threatened on the IUCN Red List; CITES, 2019), there is an urgent need to develop conservation strategies, but this is hampered by a paucity of information on cycad distribution.

Cycads grow slowly, can live for several hundred years and struggle to survive in disturbed habitats, making them important indicators of habitats in good conservation status (Norstog \& Nicholls, 1997). Assessing cycad distribution could thus contribute to the mapping of priority areas for ecosystem conservation in Mexico. The most threatened vegetation types in Mexico are oak, pine-oak and cloud forests, which occur widely in the Sierra Madre Oriental and are characteristic habitats for most species of Ceratozamia (Contreras-Medina, 2004).

The Cycad Action Plan (Donaldson, 2003) is an international initiative of the IUCN Cycad Specialist Group focusing on sustainable use and ex situ conservation. These approaches have led to a number of international initiatives (Graham et al., 2011; Griffith et al., 2015), with the main focus being on the cultivation of cycads in nurseries. This is also the case in Mexico, where the most frequently proposed conservation action has been the establishment of nurseries to support sustainable management of cycads, which are often planted for ornamental purposes (Vovides \& Iglesias, 1994; Vovides et al., 2002).

The conservation of Ceratozamia is hampered by poor taxonomic curation of botanical specimens deposited in 
Mexican herbaria and elsewhere, lack of taxonomic revisions and limited knowledge of the taxonomic relationships of species within the genus. To study the biology of species, delimit species distributions and assess extinction risk, correct identification and naming of species is important (Wheeler et al., 2012; Mota-Vargas \& Rojas-Soto, 2016), but the distribution of the various species of Ceratozamia in the Sierra Madre Oriental remains poorly known. Some Ceratozamia species occur within designated protected areas, but how many or which ones is unknown.

Ecological niche modelling predicts the distribution of species using spatial analysis of environmental variables (Holt, 2009). It is a valuable tool for the development and evaluation of conservation strategies (Peterson et al., 2006) and has been shown to be effective in studies of the distribution of many taxa (Mota-Vargas \& Rojas-Soto, 2012; Peterson \& Soberón, 2012), but has rarely been used in analyses of the distribution of cycads.

Evidence of the effectiveness of current conservation actions for Mexican Ceratozamia species is lacking. Outcomes of ongoing conservation programmes, which involve participation of local communities in the propagation and care of nursery plants, have not been evaluated (Vovides et al., 2010), and potential conceptual and methodological shortcomings that could restrict their success have not been considered (Bottrill \& Pressey, 2012). In addition, there is a disconnect between conservation policies and management strategies recommended by biologists and the needs and activities of local communities. This calls for collaborative, multidisciplinary approaches, with the aim to implement conservation strategies in partnership between local communities and conservation biologists/managers (Orlove \& Brush, 1996).

Here, we evaluate the conservation and management strategies for Ceratozamia in the Sierra Madre Oriental, using multidisciplinary methods from both natural and social sciences (Halme et al., 2015; Bennett, 2016). Specifically, we examine the taxonomy and biogeographical characteristics of the genus, and local perceptions of, and attitudes towards, existing conservation programmes. We also discuss prospects for additional multidisciplinary approaches for the conservation of cycads.

\section{Study area}

The Sierra Madre Oriental is a mountain range that emerges from the coastal plain of the Gulf of Mexico towards the central high plateau of Mexico. It is $800 \mathrm{~km}$ long and 80$100 \mathrm{~km}$ wide (Eguiluz de Antuñano et al., 2000). Ceratozamia species occur at an altitude of 600-2,000 m on karstic rocks. People living in this area are ethnically diverse and practice subsistence- and market-oriented production (Toledo et al., 2003).

\section{Methods}

\section{Species data}

We obtained occurrence records for Ceratozamia by reviewing the 323 specimens available in the following herbaria: CHAPA, CIB, ENCB, FCME, FTG, GH, HEM, IEB, K, LE, LSU, MB, MICH, MEXU, MO, NY, P, SERO, SLPM, U, UAT, US, XAL, and XALU (acronyms according to Index Herbariorum; Thiers, 2019). This review was based on the taxonomic concepts of species proposed by NicolaldeMorejón et al. (2014) and Martínez-Domínguez et al. (2018). We also included information collected in the field during 2014-2017. We conducted fieldwork on 41 Ceratozamia populations throughout the Mexican Sierra Madre Oriental, to corroborate existing records and/or obtain new localities for species. Because of the clustered distribution of species, we used preliminary information on distribution and ecological requirements to locate Ceratozamia populations. In 22 localities we interviewed local people, showing them photographs and describing the morphological characters representative of the genus, and asking about potential sites in the vicinity that may have suitable habitat for cycads, such as karstic rocks. We recorded the geographical coordinates of each site where we located cycad plants and compiled this information in a database in ArcMap 10.2 (Esri, Redlands, USA). Records without precise locality data, or with coordinates that could not be corroborated during fieldwork, were omitted. To examine the distribution of Ceratozamia in the Sierra Madre Oriental, we superimposed the points of occurrence on the biogeographical province proposed by Paniagua \& Morrone (2009).

\section{Environmental layers, ecological niche modelling and distribution}

We used interpolated climatic layers of 19 bioclimatic variables from WorldClim (Hijmans et al., 2005) at a spatial resolution of $3 \mathrm{O}^{\prime \prime}$ (c. $1 \mathrm{~km}^{2}$ cell size) to characterize ecological niches. We reduced dimensionality and collinearity between the bioclimatic layers by applying principal component analysis (PCA) with the function PCARaster in the $R$ 3.3.1 package ENMGadgets (Barve \& Barve, 2013; R Development Core Team, 2018). We retained the first six components for modelling because they explained c. $95 \%$ of the overall variance in environments for all species. Niche modelling was performed with Maxent (Phillips et al., 2006) because of its high predictive capability with presence-only data (Elith et al., 2010), and the dismo package (Hijmans et al., 2011) in $R$. Because the seeds of cycads are dispersed mainly by gravity (rarely by rodents, and then only over short distances), watersheds could be barriers to the dispersion of the species. We calibrated models within the accessible area (i.e. the area where the species could occur considering 
dispersion barriers and the historic conditions in the region) for each species (Barve et al., 2011). We used polygons representing the watershed system of Mexico, and selected those polygons where at least one record was present. Because of the small number of records, we used $80 \%$ of occurrences for calibration. Models included five bootstraptype replicas, and we selected those with the highest value for the area under the receiver operating characteristic curve (AUC). We transformed the predictions obtained into a binary map ( $0=$ absence, $1=$ presence $)$, including the total number of records in all cases corresponding to the lowest presence threshold (i.e. the minimum training presence of Maxent). We validated model predictions for species with $<20$ presence records through jackknife tests (Pearson et al., 2007); for species with $\geq 20$ records, analyses were conducted with PartialROC (Barve, 2008; Peterson et al., 2008; Supplementary Table 1).

\section{Evaluation of current conservation and management strategies}

The binary models were summed using the Algebra map tool in ArcMap, and then reclassified to produce a richness accumulation map. Although this method could potentially overestimate species richness in some areas, we believe it is suitable here because it did not predict areas that would not be suitable for Ceratozamia (e.g. Calabrese et al., 2014; D'Amen et al., 2015a,b). To visualize areas potentially affected by anthropogenic land-use changes, we clipped species richness maps using the most recent series of data on land use and vegetation coverage provided by the Mexican Instituto Nacional de Geografía y Estadística (INEGI, 2013). To assess the role of protected areas programmes, we evaluated species richness in areas of four protection categories: State, Municipal, Common Land and Private Natural Protected Areas, following the Mexican Comisión Nacional para el Uso y Conservación de la Biodiversidad (CONABIO, 2015) and the Federal Natural Protected Areas 2014 of the Mexican Comisión Nacional de Áreas Naturales Protegidas (CONANP, 2014). We also considered Priority Terrestrial Regions (CONABIO, 2004) and main regions and subregions of the cloud forest in Mexico (CONABIO, 2008). In addition, we overlaid species richness concentrations upon a cultural map (Boege, 2008), to evaluate the geographical correspondence of Ceratozamia diversity with the distribution of ethnic groups.

To evaluate ex situ conservation efforts, we consulted with the curators or directors of the major botanical gardens in Mexico, either by visiting the collections or via e-mail. To assesses the contribution of botanical gardens to Ceratozamia conservation, we confirmed the species identities of live specimens kept in botanical garden collections, using the taxonomic key by Martínez-Domínguez et al.
(2018). In addition, we identified two nurseries for Ceratozamia in the Sierra Madre Oriental (Vovides et al., 2010), in the municipality of Coacoatzintla (Veracruz State): Tachinola and Dos Cerros. Both nurseries grew C. tenuis.

To examine local perceptions of the nurseries, we interviewed people with varying degrees of involvement in the management and running of these conservation facilities (Supplementary Table 2). We identified four groups of participants: (1) representatives of local municipal institutions, (2) researchers who promoted and implemented Ceratozamia conservation through nurseries, (3) members of the community who participated in nursery activities and (4) community members who did not participate (Supplementary Table 2). We also asked members of local communities about their understanding, interpretation and evaluation of conservation strategies (Bennett, 2016). During May-August 2016 we interviewed 10 local residents (nine men and one woman) from different socio-economic backgrounds. The semi-structured interviews lasted 10-30 minutes, and six were audio-recorded. Four participants did not consent to audio recordings; we took detailed notes in these cases. We asked about the participants' knowledge of the nursery, their level of participation and perceived effects of the nursery on the community (including benefits and conflicts arising during project management). All participants gave oral consent for the use of the information, and their anonymity was preserved. We analysed the interviews qualitatively following standard practices in sociocultural anthropology and ethnobiology, using the characteristics of the content to detect any trends. During the analysis, we attempted to identify any temporal changes in the development of the nurseries (Bernard, 2011; Albuquerque et al., 2014).

\section{Results}

\section{Taxonomy of Ceratozamia species in the Sierra Madre Oriental}

The distribution of Ceratozamia species in the Sierra Madre Oriental is confined to a narrow eco-climatic zone. In herbaria and during our fieldwork, we found a total of 150 unique records, with geographical coordinates, of the 14 species that occur in this Mexican province. Six species are microendemic, of which five are located in the south of the region: C. brevifrons, C. morettii and C. tenuis occur in the Sierra Norte de Puebla-Chiconquiaco region, and C. mexicana is present in the south in a part of the Antigua Basin and, to a lesser extent, in the Huatusco-Coscomatepec area (Fig. 1). Ceratozamia decumbens is distributed in the HuautlaZongolica region and in a small part of the Orizaba region (Fig. 2), and C. zaragozae is endemic to the Sierra de Álvarez (San Luis Potosí). 


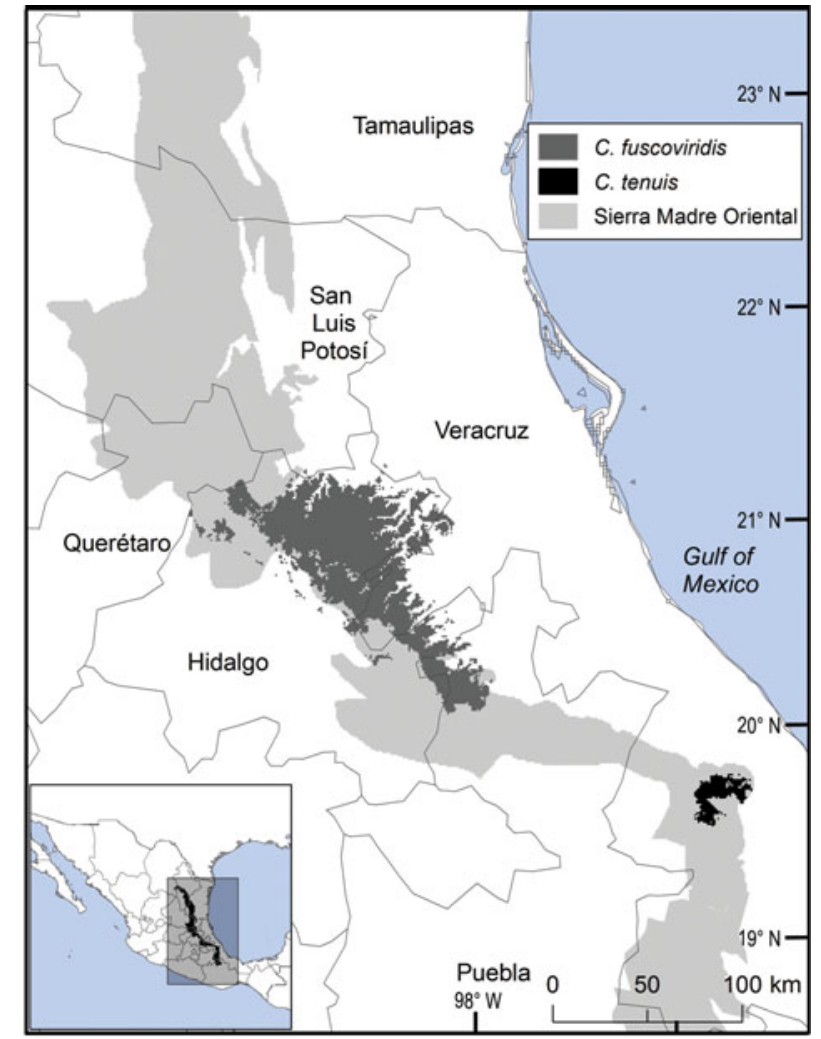

FIG. 1 Modelled potential geographical range of two species of Ceratozamia: the widely distributed $C$. fuscoviridis and the micro-endemic C. tenuis.

The remaining eight Ceratozamia species, occurring from the central area to the northern extreme of the region, have a wider distribution (Fig. 1). The species with the northernmost distribution, C. kuesteriana, occurs widely in two regions: El Cielo, and Canyons of Nuevo Leon and Tamaulipas. In the latter location, we did not locate this species during fieldwork. Ceratozamia fuscoviridis and C. totonacorum occur in the cloud forest between San Bartolo Tutotepec (Hidalgo State) and Cuetzalan (Puebla State), and in the north-west from Hidalgo to Huayacocotla in Veracruz (Fig. 2). The distribution of C. totonacorum includes part of the Sierra Norte de Puebla-Chiconquiaco region. Ceratozamia hildae and C. latifolia are located in north-west Hidalgo and as far as Huayacocotla, with vestiges in the San Luis Potosí region; the potential distributions for these two species overlap almost completely. Ceratozamia delucana is restricted to the Sierra Norte de Puebla-Chiconquiaco region and to a small cloud forest area in north-west Hidalgo and Huayacocotla, whereas C. chamberlainii and C. sabatoi inhabit a single forest area (Fig. 2).

\section{Species richness and land use}

We observed two areas of particularly high species richness. One was in the northern part of the study area, where five species with wide distributions converge, and for which the model predicted suitable ecological conditions for the presence of up to three additional species. The second area was in the south, with mainly micro-endemic species (Fig. 3). Of the total range of Ceratozamia, $46 \%$ has been converted to anthropogenic environments (Fig. 4). Species with the smallest potential range occur in the southern area, which has been largely transformed. Agriculturally driven environmental degradation is most severe within the range of $C$. mexicana (Table 1); in contrast, undisturbed natural habitats persist in the northern area. Ceratozamia latifolia and $C$. hildae have a greater potential range in areas with original vegetation (Figs $3 \& 4$ ).

\section{Assessment of conservation status and management strategies}

Most Ceratozamia species (92\%) are under ex situ conservation in botanical gardens (Table 1). These species occur in seven protected areas (Table 1). The Sierra Gorda Biosphere Reserve contains three species (C. chamberlainii, C. sabatoi and C. hildae). According to their potential range, C. kuesteriana and C. fuscoviridis could occur in the Altas Cumbres Federal Reserve, in the Chicamole ecological preservation municipal area (Fig. 5a), but we were unable to confirm this during fieldwork.

The distribution of Ceratozamia mostly overlaps with several priority areas for conservation, including areas of high species richness in the northern part of the study area. This area is thus of particular importance for the conservation of the genus (Fig. 5b). The range of Ceratozamia in the mountains of the north and central Sierra Madre Oriental, and the southern part of the range of the genus, overlap with three priority biological and cultural areas for conservation and development (Fig. 3). Forests are less affected by anthropogenic pressures in two of these areas (Fig. 4). According to their current categorization in the IUCN Red List (IUCN, 2017) and the Mexican list of threatened species, NOM-059-SEMARNAT-2010 (SEMARNAT, 2010), the species with the highest risk of extinction are those that have experienced less habitat loss. For example, C. kuesteriana has a relatively broad distribution but is categorized as Critically Endangered on the IUCN Red List. In contrast, C. mexicana is categorized as Vulnerable but occurs in an area with rapid loss of habitat (Supplementary Table 3, Figs $2 \mathrm{c} \& 4$ ). This suggests that the extinction risk of these species should be re-evaluated to align the categorization with actual threat levels.

In our survey of the two nurseries, we found that although approaches varied, outcomes were similar. Tachinola nursery is an Ejidal organization (a form of communal property/ territory common in rural Mexican regions) in operation since 1995, whereas Dos Cerros nursery is a private initiative 


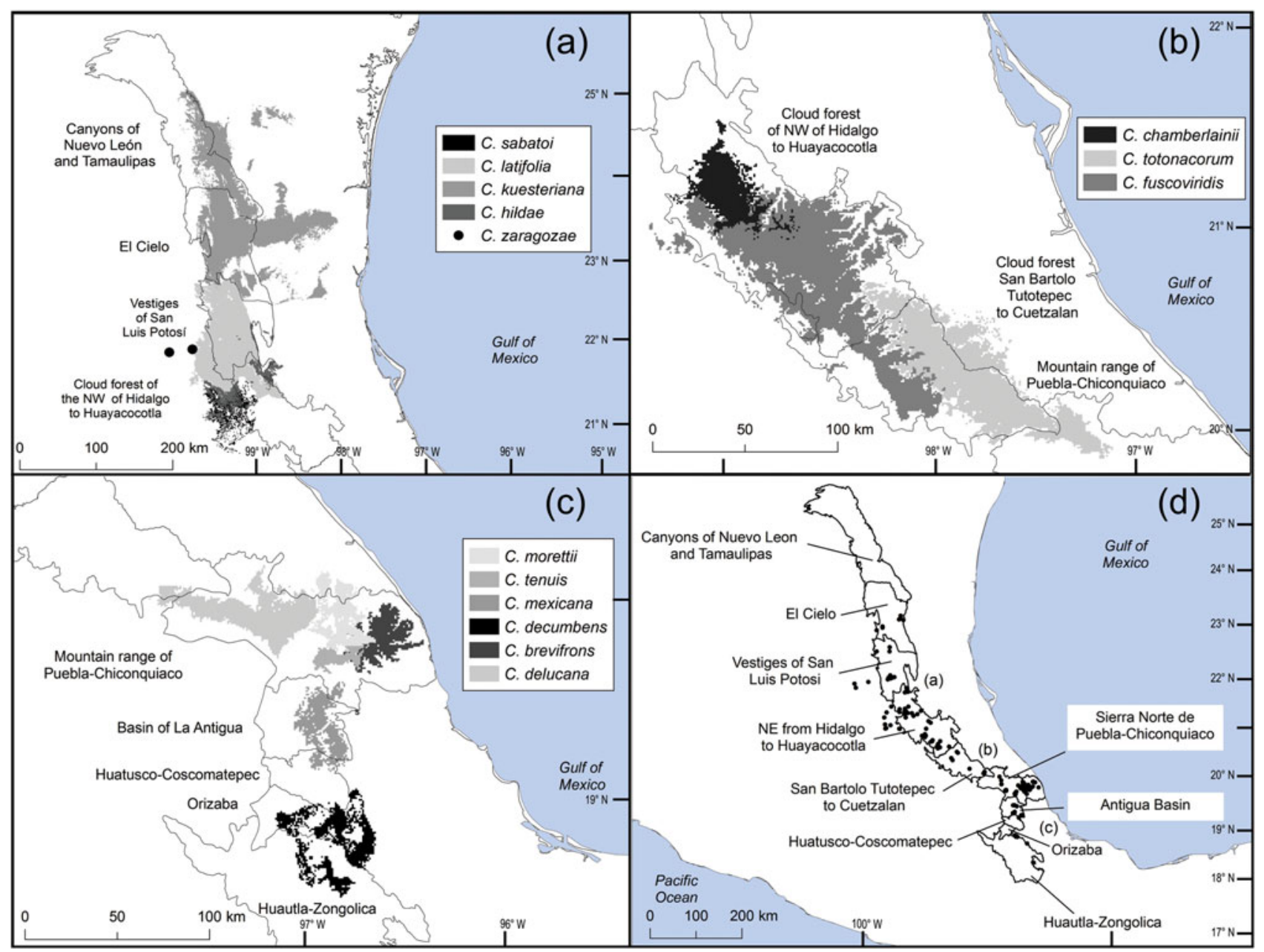

FIG. 2 Modelled potential geographical distribution for Ceratozamia: (a) northern area, (b) southern area, (c) central area,

(d) Ceratozamia species and subregions of cloud forest in Sierra Madre Oriental.

that started in 2006 and ceased to operate around 2014 In the case of Tachinola nursery, the conservation actions taken involved seed collections in the wild and transplanting of parental plants from wild populations, to protect them from potential destruction of their habitat. Both nurseries had three goals: (1) conservation of C. tenuis, (2) awarenessraising through social outreach and (3) contribution to the community's economy. Economically, Tlachinola provided benefits in the form of cash payments to community members who participated in cultivation and plant care, and Dos Cerros provided cash payments to community members for helping to transplant Ceratozamia plants, and to nursery managers for carrying out organizational tasks.

In both Tlachinola and Dos Cerros, local informants reported difficulties in the commercialization of plants (few or no sales of cycads) as a cause for the decline of the nurseries. Other reasons included low prices of plants sold, and excessive investment of time in relation to perceived benefits, which is in part because of the slow growth of the species. Overall, attitudes of local people towards Ceratozamia conservation through nurseries were negative. In response to our questions about future development and further outcomes of nursery management, most community informants recognized the failure of these initiatives. We found three additional problems: (1) organizational difficulties caused by lack of agreements between technical researchers and members of the community regarding the sale of plants, (2) lack of direct involvement of the communities in the management and operation of nurseries, and (3) absence of a marketing strategy to commercialize the cycad plants grown in nurseries. Several conflicts within and outside the community affected the work. For example, information on the progress of plant sales was not shared with all members of the community, and restrictions on the use of natural resources were imposed by authorities (use of the species is prohibited, except as ornaments on Catholic altars, and the use of seeds for food).

Our interviews showed that community members and the conservation researchers promoting and implementing conservation through nurseries differed in their conceptual framing of Ceratozamia conservation. Local people perceived conservation as protection of the natural resources 


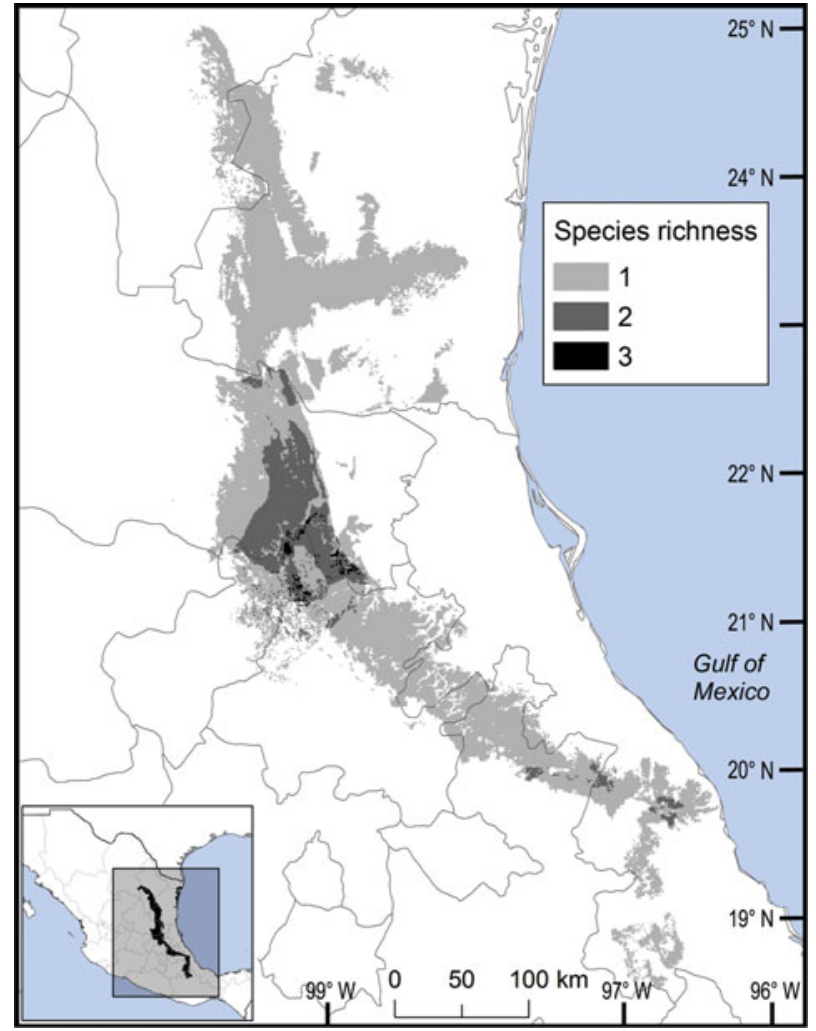

FIG. 3 Modelled potential species richness of Ceratozamia and priority biocultural regions for conservation and development.

on which they depend, whereas researchers viewed conservation primarily as a means of protecting wildlife from extinction.

\section{Discussion}

Through a multidisciplinary approach that links ecological and social aspects, we explored current conservation strategies for Ceratozamia, a genus of cycads in Mexico. Our data contribute to the understanding of the limits of conservation efforts, and demonstrate challenges for future studies. We combined an exhaustive review of occurrence records in herbaria with the taxonomic concepts proposed by Martínez-Domínguez et al. (2018) and found that reliable taxonomic information on Ceratozamia is lacking, which creates difficulties for the assignment of threat categories (Supplementary Table 3).

\section{Limitations of current conservation strategies}

Current protected areas cover only a part of the northern area of the Sierra Madre Oriental, the area with the highest potential suitability for Ceratozamia (Fig. 5a). This corresponds with a recent evaluation of the diversity of endemic species in the northern part of the study area (Salinas-Rodríguez et al., 2018); however, we found that

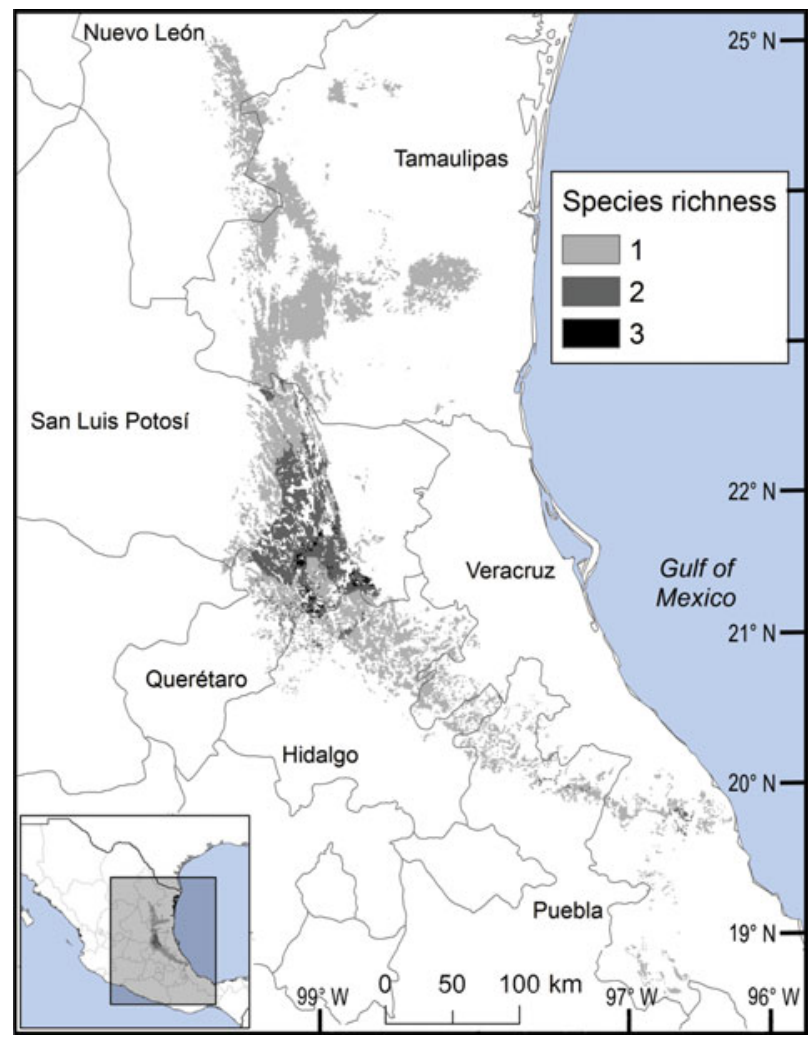

FIG. 4 Modelled potential species richness of Ceratozamia in the Sierra Madre Oriental (inset: potential geographical distribution of Ceratozamia).

the main conservation challenges are in the southern region, which was not evaluated in that study. Species in the southern area have restricted ranges, leaving them vulnerable to habitat destruction and extinction (Fig. 1). Across the state of Veracruz, where both diversity and endemism of Ceratozamia species are high, the areas with the highest concentrations of species richness are unprotected (Fig. 5). Despite occurring within a protected area, species such as C. delucana and C. decumbens have lost more than half of their potential habitat to destruction (Table 1).

Anthropogenic land-use changes affect protected areas in the study region (Fig. 4); the southern zone of the Sierra Madre Oriental is one of the most threatened, with severely transformed vegetation (Fig. 3). Therefore, species in the southern zone of the restricted distribution of Ceratozamia require urgent conservation planning. There is considerable overlap between the distribution of Ceratozamia and the main Priority Terrestrial Regions for Conservation (Fig. 4) defined by Mexican authorities. These areas are considered relevant for the conservation of many other plant and animal taxa, but forest cover continues to decline. This suggests that current protected areas are ineffective in conserving species endemic to Mexico. In this context, cycads could serve as biogeographical and ecological model species in conservation biology studies, as they occur in heterogeneous habitats and are frequently associated with other 
TABLE 1 The area where each species is predicted to be present, area transformed to anthropogenic landscapes, whether the area is considered a biocultural priority region (Boege, 2008), and conservation strategies for Ceratozamia species in the Sierra Madre Oriental, Mexico.

\begin{tabular}{|c|c|c|c|c|}
\hline Species & $\begin{array}{l}\text { Predicted area } \\
\left(\mathrm{km}^{2}\right)\end{array}$ & $\begin{array}{l}\text { Transformed } \\
\text { habitat }\left(\mathrm{km}^{2}\right)\end{array}$ & $\begin{array}{l}\text { Biocultural } \\
\text { priority region }\end{array}$ & Conservation category \\
\hline C. brevifrons & 817 & 558 & No & Ex situ: botanical garden \\
\hline C. chamberlainii & 3,604 & 2,762 & Yes & $\begin{array}{l}\text { Ex situ: botanical garden } \\
\text { In situ: Biosphere Reserve Sierra Gorda }\end{array}$ \\
\hline C. decumbens & 1,084 & 836 & Yes & $\begin{array}{l}\text { Ex situ: botanical garden } \\
\text { In situ: State Reserve Metlac-Río Blanco }\end{array}$ \\
\hline C. delucana & 1,642 & 1,118 & Yes & $\begin{array}{l}\text { Ex situ: botanical garden } \\
\text { In situ: State Reserve Río Filolobos \& surroundings }\end{array}$ \\
\hline C. fuscoviridis & 6,674 & 3,593 & Yes & $\begin{array}{l}\text { Ex situ: botanical garden } \\
\text { In situ: Los Mármoles National Park }\end{array}$ \\
\hline C. hildae & 6,631 & 2,206 & Yes & $\begin{array}{l}\text { Ex situ: botanical garden } \\
\text { In situ: Biosphere Reserve Sierra Gorda }\end{array}$ \\
\hline C. kuesteriana & 19,599 & 8,748 & Yes & $\begin{array}{l}\text { Ex situ: botanical garden } \\
\text { In situ: Biosphere Reserve El Cielo }\end{array}$ \\
\hline C. latifolia & 8,148 & 2,729 & Yes & Ex situ: botanical garden \\
\hline C. mexicana & 737 & 647 & No & Ex situ: botanical garden \\
\hline C. morettii & 782 & 535 & No & Ex situ: botanical garden \\
\hline C. sabatoi & 1,447 & 524 & Yes & $\begin{array}{l}\text { Ex situ: botanical garden } \\
\text { In situ: Biosphere Reserve Sierra Gorda, } \\
\text { Los Mármoles National Park }\end{array}$ \\
\hline C. tenuis & 258 & 203 & No & $\begin{array}{l}\text { Ex situ: botanical garden, nursery Tlachinola (inactive), } \\
\text { nursery Dos Cerros (closed) }\end{array}$ \\
\hline C. totonacorum & 4,345 & 1,073 & Yes & In situ: hydrological basin of River Necaxa \\
\hline C. zaragozae & Not available & Not available & No & $\begin{array}{l}\text { Ex situ: botanical garden } \\
\text { In situ: El Potosí National Park }\end{array}$ \\
\hline
\end{tabular}

endemic species. In situ conservation actions are required to mitigate the loss of diversity in these cloud forests, which comprise highly diverse and productive ecosystems in Mexico (Gual-Díaz \& González-Medrano, 2014).

Ex situ conservation initiatives have dominated the preservation of cycads in Mexico, with botanic gardens playing an important role (Griffith et al., 2015). However, species that occur in a narrow geographical area, and/or are strictly dioecious, tend to have reduced ranges and populations when their habitats are fragmented by human activities. This leaves them more vulnerable to extinction than species with a broader distribution. Conserving Ceratozamia species and other cycad genera such as Dioon and Zamia requires improved conservation strategies and careful selection of the best strategy depending on the characteristics of the species and the area in which it occurs.

\section{Improving conservation strategies through multidisciplinary approaches}

The best preserved areas for Ceratozamia in the Sierra Madre Oriental, which potentially include the highest number of cycad species (except the range of C. decumbens; Fig. 3), correspond with priority biocultural regions. These are territories with long-term occupation by Indigenous peoples and peasant communities of Mesoamerican origin, and are characterized by high levels of biological, agrobiological and cultural diversity (Boege, 2008). The fact that these areas harbour a large number of Ceratozamia species could be a result of the past activities of diverse Mesoamerican peoples, who have managed natural resources without destroying or severely damaging the forest (Toledo et al., 2003). Our findings suggest that, in addition to considering the biology of the target taxa, successful conservation and management of threatened species must enable active and direct participation of local communities. This community engagement should not be limited to the provision of economic benefits during the implementation of conservation projects, but should start during the planning phase, to avoid negative perceptions of, and attitudes towards, conservation and management strategies.

We detected a series of conflicts in the nurseries studied, such as a lack of dialogue between members of the community and researchers, discontent and distrust within the community, difficulty selling the plants, and organizational problems (lack of agreements). In both nurseries, Thachinola and Dos Cerros, members of local communities were considered as employees, rather than principal participants. The nature of these conflicts could vary regionally because of diverse factors (e.g. social values, socio-economic status). Our work could serve as a starting point for a comprehensive analysis of nurseries management. Development 


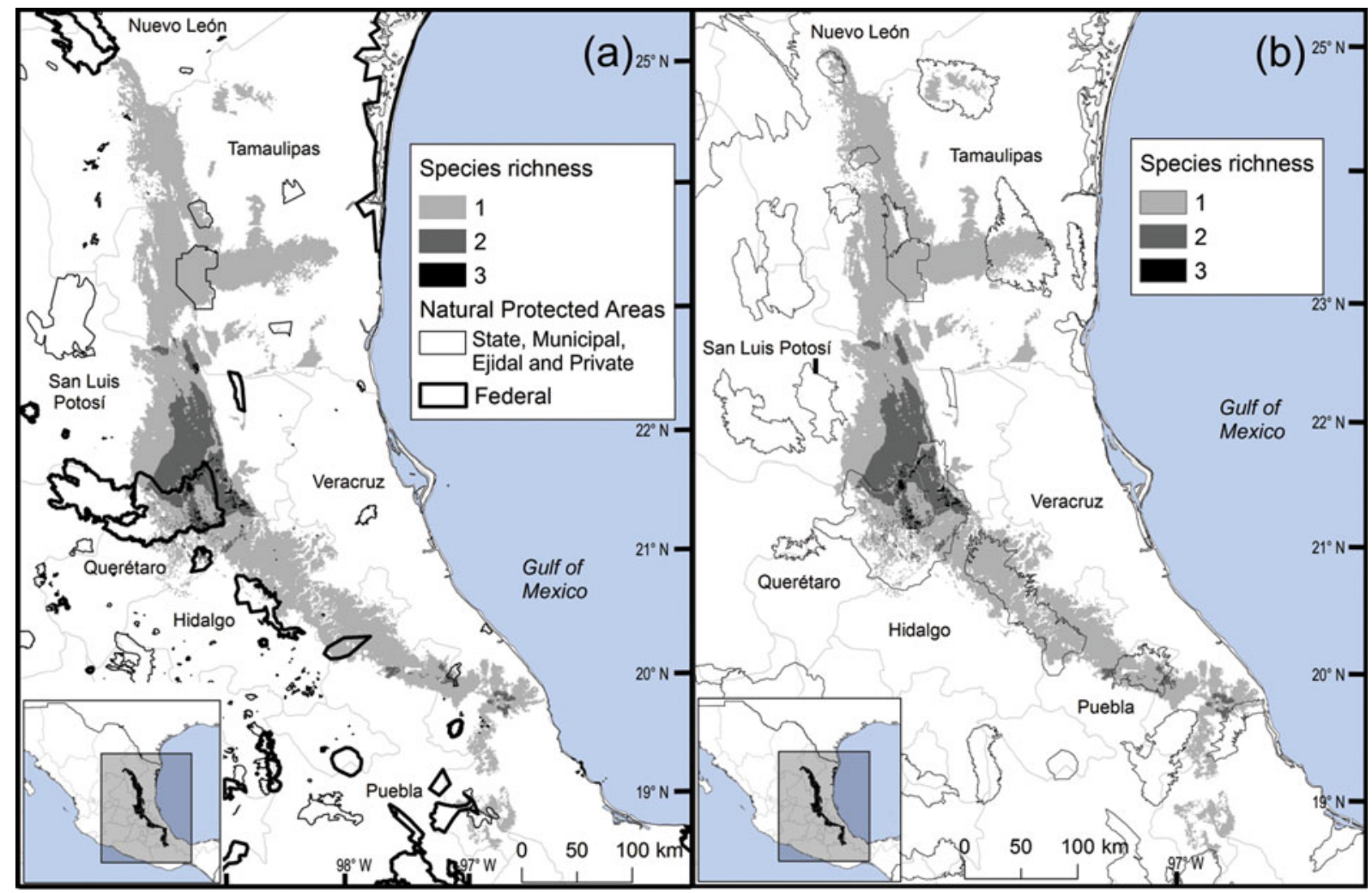

FIG. 5 Modelled potential species richness of Ceratozamia and (a) protected areas, and (b) Priority Terrestrial Regions for Conservation (CONABIO, 2004).

of a more complex socio-environmental framework is necessary to plan any further establishment of cycad nurseries in the communities in the study area. We recommend that communities should be involved in conservation planning from the start, as principal actors, in coordination with the developers of planning processes. In addition, the current practice of cultivating a single species could be replaced with diversified models featuring a range of products and practices, such as cultivation of cycads and other species with faster growth rates, or inclusion of recreational activities such as tourist trails.

Overall, our findings suggest that the conservation status of most Ceratozamia species needs to be re-evaluated. In particular, the threat categories used in Mexican legislation need to be updated (Figs $2 \& 4$ ). Considering that most cycad species in this area have cultural importance as religious symbols (Bonta et al., 2019), a re-evaluation of the relationship between cycads and people is important for the conservation of this group. We recommend community-managed protected areas to improve conservation effectiveness, and the incorporation of traditional knowledge in the planning and implementation of conservation actions (Berkes, 2009; Shahabuddin \& Rao, 2010). This is particularly applicable in priority areas for biocultural conservation and development that have a high species richness, such as those harbouring C. sabatoi, C. hildae, C. kuesteriana, C. zaragozae and C. fuscoviridis (Fig. 3). Working at the scale of ecosystem conservation, several studies have pointed out the need to combine approaches from basic and applied and/or social science, and to apply a holistic perspective to complex problems (Lindenmayer \& Hunter, 2010). Biodiversity conservation requires both information on species' biology, and acceptance of science-based programmes by communities, whose priorities and viewpoints need to be considered. Conservation strategies thus need to be evaluated from a multidisciplinary perspective, through assessment of ecological and taxonomic issues combined with an examination of social perceptions. Such collaborative approaches have the potential to improve the effectiveness of ex situ conservation strategies for Ceratozamia and other taxa.

Acknowledgements This research was supported in part by Consejo Nacional de Ciencia y Teconología under grant 134960 to FNM, and National Science Foundation grants BSR-8607049 and EF-0629817 to DWS. LMD thanks CONACYT for the award of a Masters degree scholarship. We thank C. Yañez-Arenas and S. Jiménez-García for advice on ecological niche modelling and the socio-cultural anthropology aspects, respectively; the curators of all herbaria; the communities in the municipality of Coacoatzintla for their cooperation; the anonymous reviewers for their constructive critiques; and the editors for their extensive help in finalizing the text.

Author contributions Study design: LMD, FNM, FVS; data collection: LMD, FNM; data analysis: LMD, FNM, ORS; writing and revisions: all authors. 


\section{Conflicts of interest None.}

Ethical standards We obtained permission to conduct this research within the community from community representatives, and informed consent from interviewees. This research complied with the Oryx guidelines on ethical standards and the Ethical Code of the American Sociological Association.

\section{References}

Albuquerque, U.P., Fernandes Cruz da Cunha, L.V., Farias Paiva de Lucena, R. \& Nóbrega-Alvez, R.R. (2014) Methods and Techniques in Ethnobiology and Ethnoecology. Humana Press/ Springer, New York, USA.

B ARVE, N. (2008) Tool for Partial-ROC, version 1.o. Biodiversity Institute, Lawrence, USA.

Barve, N. \& Barve, V. (2013) ENMGadgets: Tools for Pre and Post Processing in ENM Workflows. github.com/vijaybarve/ ENMGadgets [accessed 26 June 2020].

Barve, N., Barve, V., Jiménez-Valverde, A., Lira-Noriega, A., Mahera, S.A., Peterson, A.T. et al. (2011) The crucial role of the accessible area in ecological niche modeling and species distribution modeling. Ecological Modelling, 222, 1810-1819.

BenNetT, N.J. (2016) Using perceptions as evidence to improve conservation and environmental management. Conservation Biology, 30, 582-592.

BERKES, F. (2009) Community conserved areas: policy issues in historic and contemporary context. Conservation Letters, 2, 19-24.

Bernard, H.R. (2011) Research Methods in Anthropology. Qualitative and Quantitative Approaches, 5 th edition. AltaMira Press, Plymouth, UK.

Boege, E. (2008) El Patrimonio Biocultural de los Pueblos Indígenas de México, 1st edition. Instituto Nacional de Antropología e Historia, Comisión Nacional para el Desarrollo de los Pueblos Indígenas, Mexico City, Mexico.

Bonta, M., Pulido-Silva, M.T., Diego-Vargas, T., Vite-Reyes, A., Vovides, A.P. \& Cibrián-Jaramillo, A. (2019) Ethnobotany of Mexican and northern Central American cycads (Zamiaceae). Journal of Ethnobiology and Ethnomedicine, 4, 15.

Bottrill, M.C. \& Pressey, R.L. (2012) The effectiveness and evaluation of conservation planning. Conservation Letters, $5,407-420$.

Calabrese, J.M., Certain, G., Kraan, C. \& Dormann, C.F. (2014) Stacking species distribution models and adjusting bias by linking them to macroecological models. Global Ecology and Biogeography, 23, 99-112.

Calonje, M., Stevenson, D.W. \& Osborne, R. (2019) The World List of Cycads, online edition. cycadlist.org [accessed 20 September 2019].

CITES (2019) Convención Sobre el Comercio Internacional de Especies Amenazadas de Fauna y Flora Silvestres. CITES, Gevena,

Switzerland. cites.org/esp/disc/text.php [accessed 27 October 2019].

CONABIO (2004) Regiones Terrestres Prioritarias. Escala 1:1000ooo. Comisión Nacional para el Conocimiento y Uso de la Biodiversidad (CONABIO), Mexico City, Mexico. conabio.gob.mx/informacion/ gis [accessed 27 May 2017].

CONABIO (2008) Principales Regiones y Subregiones del Bosque Mesófilo de Montaña en México. Comisión Nacional para el Conocimiento y Uso de la Biodiversidad (CONABIO), Mexico City, Mexico. conabio.gob.mx/informacion/gis [accessed 20 May 2018].

CONABIO (2015) Áreas Naturales Protegidas Estatales, Municipales, Ejidales y Privadas de México, 1st edition. Comisión Nacional para el Conocimiento y Uso de la Biodiversidad
(CONABIO), Mexico City, Mexico. conabio.gob.mx/ informacion/gis [accessed 25 May 2017].

CONANP (2014) Áreas Naturales Protegidas Federales de México. Escala: 1:0, 1st edition. Comisión Nacional de Áreas Naturales Protegidas (CONANP), Mexico City, Mexico. conabio.gob.mx/ informacion/gis [accessed 25 May 2017].

Contreras-Medina, R. (2004) Gimnospermas. In Biodiversidad de la Sierra Madre Oriental (eds I. Luna, J.J. Morrone \&

D. Espinosa-Organista), pp. 137-148. National Autonomous University of Mexico, Mexico City, Mexico.

D’Amen, M., Dubuis, A., Fernandes, R.F., Pottier, J., Pellissier, L. \& GUISAN, A. (2015a) Using species richness and functional traits predictions to constrain assemblage predictions from stacked species distribution models. Journal Biogeography, 42, 1255-1266.

D’Amen, M., Pradervand, J.N. \& Guisan, A. (2015b) Predicting richness and composition in mountain insect communities at high resolution: a new test of the SESAM framework. Global Ecology Biogeography, 24, 1443-1453.

Donaldson, J.S. (2003) Cycads: Status Survey and Conservation Action Plan. IUCN/SSC Cycad Specialist Group, IUCN, Gland, Switzerland and Cambridge, UK.

Eguiluz de Antuñano, S., Aranda-García, M. \& Marrett, R. (200o) Tectónica de la Sierra Madre Oriental, México. Boletín de la Sociedad Geológica Mexicana, LIII, 1-26.

Elith, J., Kearney, M. \& Phillips, S.J. (2010) The art of modelling range-shifting species. Methods in Ecology and Evolution, 1, 330-342.

Graham, D.A., Bonta, M.A. \& UlloA, R. (2011) Cycad conservation, peasant subsistence, and the military coup in Honduras. Society and Natural Resources, 24, 193-200.

Griffith, M.P., Calonje, M., Meerow, A.W., Tut, F., Kramer, A.T., Hird, A. et al. (2015) Can a botanic garden cycad collection capture the genetic diversity in a wild population? International Journal of Plant Science, 176, 1-10.

Gual-Díaz, M. \& González-Medrano, F. (2014) Los bosques mesófilos de montaña en México. In Bosques Mesófilos de Montaña de México: Diversidad, Ecología y Manejo (eds M. Gual-Díaz \& A. Rendón-Correa), pp. 27-67. Comisión Nacional para el Conocimiento y Uso de la Biodiversidad (CONABIO), Mexico City, Mexico.

Halme, P., Kuusela, S. \& Juslén, A. (2015) Why taxonomists and ecologists are not, but should be, carpooling? Biodiversity and Conservation, 24, 1831-1836.

Hijmans, R.J., Cameron, S.E., Parra, J.L., Jones, P.G. \& Jarvis, A. (2005) Very high resolution interpolated climate surfaces for global land areas. International Journal of Climatology, 25, 1965-1978.

Hijmans, R.J., Phillips, S.J., Leathwick, J. \& Elith, J. (2011) Dismo: Species Distribution Modeling, R Package, version 0.7-17. CRAN. R-project.org/package=dismo [accessed November 2020].

Holt, R.D. (2009) Bringing the Hutchinsonian niche into the 21st century: ecological and evolutionary perspectives. Proceedings of the National Academy of Science of the United States of America, 106, 19659-19665.

INEGI (2013) Uso del Suelo y Vegetación Escala 1:250 ooo, serie V. Instituto Nacional de Estadística y Geografía (INEGI), Mexico City, Mexico. conabio.gob.mx/informacion/gis [accessed 25 February 2017].

IUCN (2017) The IUCN Red List of Threatened Species. IUCN, Gland, Switzerland. iucnredlist.org [accessed 13 December 2017].

Lindenmayer, D. \& Hunter, M. (2010) Some guiding concepts for conservation biology. Conservation Biology, 24, 1459-1468.

Martínez-Domínguez, L., Nicolalde-Morejón, F., Vergara-Silva, F. \& Stevenson, D.W. (2018) Taxonomic review of Ceratozamia (Zamiaceae) in the Sierra Madre Oriental, Mexico. PhytoKeys, 100, 91-124. 
Mota-Vargas, C. \& Rojas-Soto, O. (2012) The importance of defining the geographic distribution of species for conservation: the case of the bearded wood-partridge. Journal for Nature Conservation, 20, 10-17.

Mota-Vargas, C. \& Rojas-Soto, O. (2016) Taxonomy and ecological niche modeling: implications for the conservation of wood partridges (genus Dendrortyx). Journal of Nature Conservation, 29, 1-13.

Nicolalde-Morejón, F., González-Astorga, J., Vergara-Silva, F., Stevenson, D.W., Rojas-Soto, O. \& Medina-Villarreal, A. (2014) Biodiversidad de Zamiaceae en México. Revista Mexicana de Biodiversidad, 85, S114-S125.

Norstog, K.J. \& Nicholls, T.J. (1997) The Biology of the Cycads. Cornell University Press, Ithaca, USA.

Orlove, B.S. \& BrUSh, S.B. (1996) Anthropology and the conservation of biodiversity. Annual Review Anthropology, 25, 329-352.

Paniagua, L. \& Morrone, J.J. (2009) Do the Oaxacan Highlands represent a natural biotic unit? A cladistic biogeographical test based on vertebrate taxa. Journal of Biogeography, 36, 1939-1944.

Pearson, R.G., Raxworthy, C.J., Nakamura, M. \& Peterson, T. (2007) Predicting species distributions from small numbers of occurrence records: a test case using cryptic geckos in Madagascar. Journal of Biogeography, 34, 102-117.

Peterson, A.T. \& Soberón, J. (2012) Species distribution modeling and ecological niche modeling: getting the concepts right. Natureza \& Conservacao, 10, 1-6.

Peterson, A.T., Sánchez-Cordero, V., Martínez-Meyer, E. \& Navarro-Sigüenza, A.G. (2006) Tracking population extirpations via melding ecological niche modeling with land-cover information. Ecological Modelling, 195, 229-236.

Peterson, A.T., Papes, M. \& Soberón, J. (2008) Rethinking receiver operating characteristic analysis applications in ecological niche modelling. Ecological Modelling, 213, 63-72.

Phillips, S.J., Anderson, R.P. \& Schapired, R.E. (2006) Maximum entropy modeling of species geographic distributions. Ecological Modelling, 190, 231-259.

R Development Core Team (2012) R: A Language and Environment for Statistical Computing. The R Foundation for Statistical Computing, Vienna, Austria.
Salinas-Rodríguez, M.M., Sajama, M.J., Gutiérrez-Ortega, J.S., Ortega-BÁez, P. \& Estrada-Castillón, A.E. (2018) Identification of endemic vascular plant species hotspots and the effectiveness of the protected areas for their conservation in Sierra Madre Oriental, Mexico. Journal for Nature Conservation, $46,6-27$.

Semarnat (2010) Norma Official Mexicana NOM-059SEMARNAT-2010. Secretaría de Medio Ambiente y Recursos Naturales (SEMARNAT), Mexico City, Mexico. profepa.gob.mx/ innovaportal/file/435/1 [accessed 25 February 2017].

Shahabuddin, G. \& RaO, M. (2010) Do community-conserved areas effectively conserve biological diversity? Global insights and the Indian context. Biological Conservancy, 143, 2926-2936.

Thiers, B. (2019) Index Herbariorum. A Worldwide Index of 3,100 Herbaria and 12,00o Associated Staff where a Total of 390 Million Botanical Specimens are Permanently Housed. New York Botanical Garden's Virtual Herbarium. sweetgum.nybg.org/science/ih [accessed November 2020].

Toledo, V.M., Ortiz-Espejel, B., Cortés, L., Moguel, P. \& Ordoñez, M.D.J. (2003) The multiple use of tropical forests by Indigenous peoples in Mexico: a case of adaptive management. Conservation Ecology, 7, 9.

Vovides, A.P. \& Iglesias, C.G. (1994) An integrated conservation strategy for the cycad Dioon edule Lindl. Biodiversity and Conservation, 3, 137-141.

Vovides, A.P., Pérez-Farrera, M.A., Vázquez-Torres, M. \& Schippmann, U. (2002) Peasant nurseries: a concept for an integrated conservation strategy for cycads in Mexico. In Plant Conservation in the Tropics: Perspectives and Practice (eds M. Maunder, C. Clubbe, C. Hankamer \& M. Groves), pp. 421-444. Royal Botanic Gardens, Kew, UK.

Vovides, A.P., Pérez-Farrera, M.A. \& Iglesias, C. (2010) Cycad propagation by rural nurseries in Mexico as an alternative conservation strategy: 20 years on. Kew Bulletin, 65, 603-611.

Wheeler, Q.D., Knapp, S., Stevenson, D.W., Stevenson, J., Blum, S.D., Bоом, B.M. et al. (2012) Mapping the biosphere: exploring species to understand the origin, organization and sustainability of biodiversity. Systematic Biodiversity, 10, 1-20. 